\title{
LYSOSOMAL ACTIVATION IN RELATION TO CONNECTIVE TISSUE DISEASE
}

\author{
BY \\ L. WEISS* AND J. T. DINGLE \\ Strangeways Research Laboratory, Cambridge, England
}

It has been suggested that some of the degradative changes associated with connective tissue diseases may be due to the release of hydrolytic enzymes from the lysosomes of connective tissue cells (Dingle, 1962a, b) and that these diseases may have an immunological basis (Glynn, 1962). We have attempted to test the compatibility of these two hypotheses by producing an antiserum that modifies lysosomal integrity. In view of the therapeutic activity of hydrocortisone in rheumatic diseases, preliminary studies are reported on the action of this steroid in our experimental system.

\section{Materials and Methods}

\section{Preparation of Lysosomal Fractions}

There is at present no method for separating lysosomal particles from small mitochondria. The method used in this study is a modification of the sucrose layering technique used by DeLuca and Dingle (unpublished observations), in which a light mitochondrial fraction, sedimenting between 3,000 and 5,000 g., was layered over $0.6 \mathrm{M}$ sucrose. The final $(\mathrm{F} 3)$ fraction, which was used in these studies, was obtained by centrifuging between 5,000 and 7,000 G. for 10 minutss. This fraction represents approximately a 15 -fold increase in specific activity of lysosomal enzymes and from electron micrographic studies (Glauert and Dingle, unpublished) represents a large increase in the proportion of lysosomes as compared with that in the starting material (Fig. 1). It must be emphasized, however, that this preparation still contains other cellular components.

\section{Release of Lysosomal Enzymes in vitro}

This was measured as described by Dingle (1961). Cathepsin activity was estimated with haemoglobin as substrate (as described by Anson, 1938), acid phosphatase with sodium p-nitrophenol phosphate as substrate (Torriani, 1960), and aryl sulphatase by the method of Roy (1958).

* Permanent address: Department of Experimental Pathology Roswell Park Memorial Institute, Buffalo 3, N.Y., U.S.A.

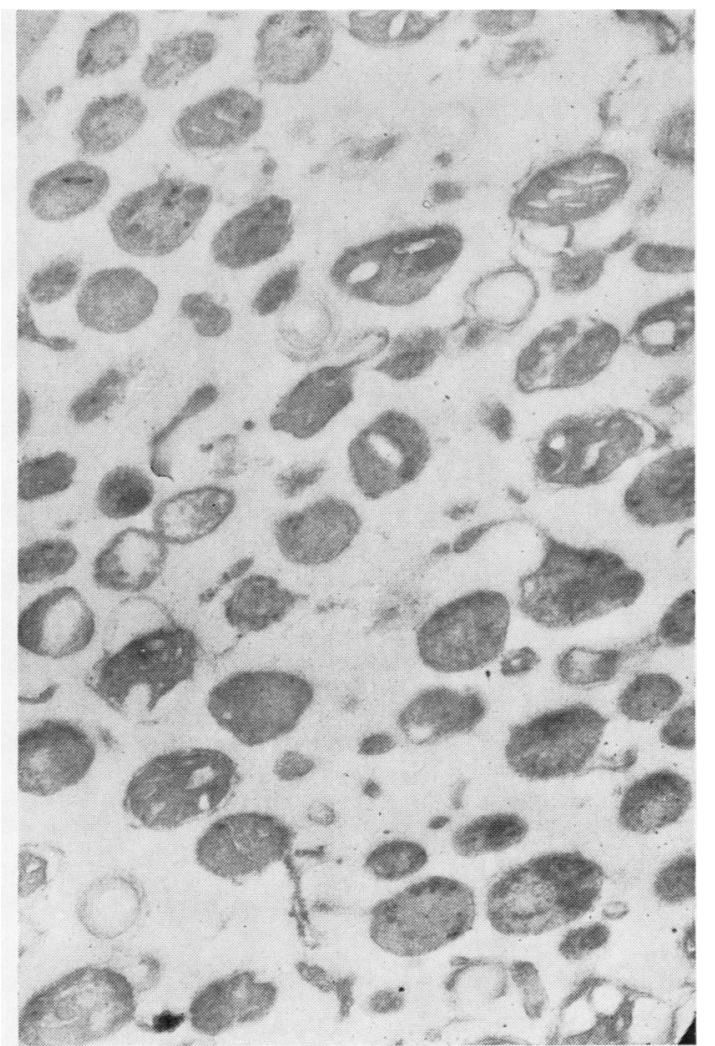

Fig. 1.-Electron micrograph of "lysosome" preparation used in the present experiments. ( $\times 18,000$ approx.)

\section{Preparation of Antiserum}

Antiserum was produced by the intraperitoneal injection into rabbits of $1 \mathrm{ml}$. of the lysosomal (F3) preparation suspended in sucrose. This preparation represents the material obtained by fractionation of approximately $20 \mathrm{~g}$. rat liver. Five injections on alternate days were followed by an interval of 15 days, after which the rabbits were given three more injections 
on alternate days and were bled 15 days after this. The serum was stored at $-20^{\circ} \mathrm{C}$. The antiserum was tested for activity by its power to agglutinate rat erythrocytes, by complement-fixation tests on incubation with the lysosomal preparation, by its ability to agglutinate tanned rabbit erythrocytes coated with the lysosomal preparation, and by its reactions with lysosomes in an Ouchterlony plate. For control purposes, antiserum was heated at $56^{\circ} \mathrm{C}$. for 30 minutes; it was absorbed with rat erythrocytes, and absorbed with a lysosomal preparation.

Action of the Antiserum upon Lysosomal Particles in vitro

A lysosomal/mitochondrial fraction (F1) from rat liver was incubated at $37^{\circ} \mathrm{C}$. in the presence of various dilutions of antiserum. The particles were suspended in $0.6 \mathrm{M}$ sucrose $+0.01 \mathrm{M}$ tris $\mathrm{pH} 7.4$; in some experiments 0.9 per cent. sodium chloride was added to the sucrose. At the end of the incubation period the suspensions were centrifuged at $15,000 \mathrm{G}$. for 20 minutes and the released enzymes estimated in the supernatant fluid.

\section{Action of Antiserum upon Rat Liver Slices}

In these experiments rat liver was sliced on a tissue chopper (McIlwain and Buddle, 1953) and the slices were placed in Krebs-Ringer-phosphate $\mathrm{pH} \mathrm{7.4} \mathrm{(Umbreit,}$ Burris, and Stauffer, 1957) in a shaking incubator at $37^{\circ} \mathrm{C}$. Samples of the suspending medium were removed at intervals and assayed for free lysosomal-enzyme activity. Samples of the tissue were also taken and homogenized and the ratio of free- and lysosomallybound hydrolases was estimated. At the end of the incubation period four samples of the liver slices were cooled in glass tubes on solid $\mathrm{CO}_{2}$ and then sectioned on a cryostat, and the sections were stained for acid phosphatase by the method of Gomori (1952). The presence of intact acid phosphatase-staining granules is thought to be a reliable indication of lysosomal integrity.

\section{Cell Cultures}

Cell cultures of a permanent strain of fibroblasts (16C) originating from neonatal rat dermis (Daniel, Dingle, and Lucy, 1961) were grown on coverslips in culture vessels similar to those described by Pulvertaft (1959). The normal culture medium was synthetic medium 199 (Morgan, Morton, and Parker, 1950) plus 15 per cent. bovine serum. The cultures were washed with Hank's balanced saline and test sera were added at a concentration of 15 per cent. in medium 199. Each experiment was made on six cultures, on at least three separate occasions. All cultures were observed by phasecontrast microscopy and some were stained for acid phosphatase (Gomori, 1952) after 2 to 4 hours' fixation in formol-calcium. Viability was tested by culturing the cells for 4 days after exposure to the test medium, by which time dead cells were obvious.

\section{Activity of Antiserum}

\section{Results}

The antiserum agglutinated rat erythrocytes at a concentration of $1 / 64$. When it reacted with lysosomes there was significant fixation of complement to a titre of 80 , and the tanned-cell titre was greater than $1: 1,000$ (control serum gave no dense agglutination). The Ouchterlony plate (Fig. 2) showed the interaction of the antiserum with the lysosomal preparation. This was abolished by previous incubation of the antiserum with lysosomes, but was not greatly affected by either heat inactivation or absorption with rat erythrocytes.

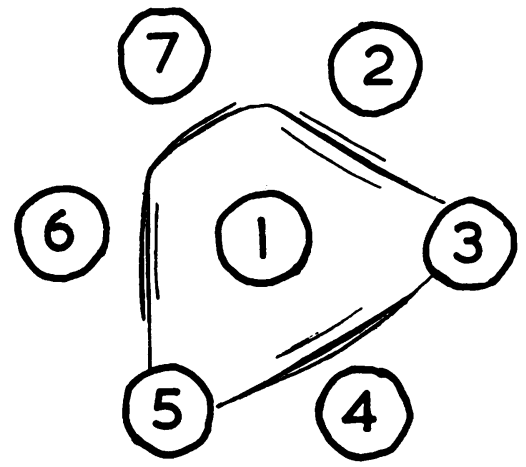

Fig. 2.-Drawing of precipitation lines in an Ouchterlony plate.
(1) "Lysosome" preparation
(2) "Antiserum" previously absorbed with rat erythrocyte
(3) Control rabbit serum
(4) Heat inactivated "antiserum"
(5) "Antiserum" previously absorbed with "lysosome" preparation
(6) "Antiserum"
(7) "Antiserum" diluted $1: 2$ in saline

\section{Effect of Antiserum on Isolated Lysosomes}

Partially purified lysosomal preparations were incubated for periods of up to 3 hours at $37^{\circ} \mathrm{C}$. with and without the antiserum; there was no release of appreciable quantities of any lysosomal hydrolases, whether the antiserum was present or not.

\section{Effect of Antiserum on Liver Slices}

One to 2 hours' incubation of rat liver slices in Krebs-Ringer-phosphate at $37^{\circ} \mathrm{C}$. with antiserum increased the release of acid phosphatase into the suspending medium. This experimental system is not ideal, since incubation of control liver slices under these conditions also releases lysosomal enzymes, although less activity is liberated than in the presence of the antiserum. When the tissues were homogenized at the end of the incubation period and the ratio of free- to lysosomally-bound enzyme was estimated, this ratio was found to be greater in the treated tissues $(1 \cdot 21)$ than in the controls $(0 \cdot 84)$; the "experimental" tissues contained less lysosomally-bound enzyme than did the controls (Fig. 3, opposite). 


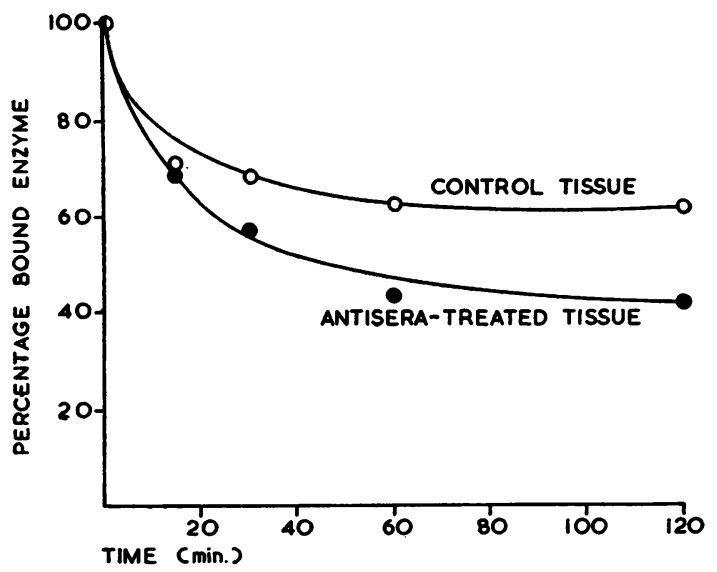

Fig. 3.-Loss of bound acid phosphatase from rat liver slices. Rat liver slices were incubated at $37^{\circ} \mathrm{C}$. in $\mathrm{Krebs}-\mathrm{Ringer-} \mathrm{PO}_{4}$ pH 7.4. Glucose $1.8 \mathrm{mg} . / \mathrm{ml}$.

The lysosomally-bound acid phosphatase remaining in the tissue was determined at intervals.

Histochemical observations on the acid phosphatase activity in these slices showed that both the control and experimental tissues contained many acid phosphatase-positive particles, and no obvious difference could be seen between the two series.

Although these results give some indication that the antiserum increases the release of lysosomal enzymes, tissue slices are not very suitable for studying the effect on the lysosomes of the interaction between the antiserum and cells. This may be due to poor uptake of the protein by the slices, to the damage caused to the tissue by slicing, or to the effect of the incubation medium upon lysosomal stability.

\section{Effect of Antiserum on Cell Cultures}

In order to study the action of the antiserum on lysosomal stability in living cells, the antiserum was added to monolayer cultures of rat dermal fibroblasts. Within a few minutes of adding a medium containing 15 per cent. of the antiserum to such cultures, the cytoplasmic processes retracted, the cells became intensely vacuolated, and the nuclear membranes appeared unduly prominent, possibly indicating a diminution in cytoplasmic refractive index. In some cells the nuclear material became granular, the nucleoli were no longer visible, and the mitochondria rounded up into dense granules. That these appearances were associated with cell death was confirmed by maintaining the cultures for 4 days. A similar cytotoxic effect was noted after cells were exposed to antiserum previously absorbed with rat erythrocytes. On the other hand, heat-inactivated antiserum and antiserum pre- viously incubated with the lysosomal preparation, had no detectable cytotoxic effect.

Staining for intracellular acid phosphatase showed that within 30 seconds of adding antiserum (or erythrocyte-absorbed antiserum) the discrete brown granules associated with the lysosomal acid phosphatase disappeared, and the brown colouration diffused throughout the whole cell (Fig. 4); after 7 minutes the brown colour had completely disappeared from the great majority of the cells. Occasionally a few cells containing intact acid phosphatase-positive granules were still present 1 hour after exposure to the antiserum (central cells in Fig. 4).

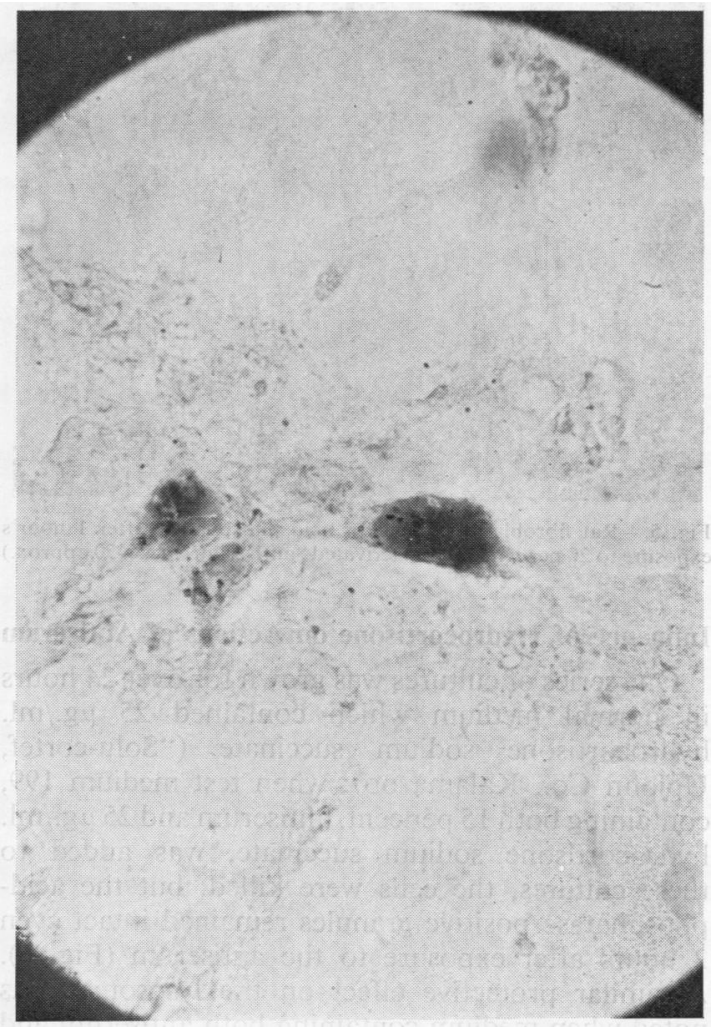

Fig. 4.-Rat fibroblasts stained for acid phosphatase after 1 hour's exposure to a 20 per cent. concentration of "antiserum". ( $\times 450$ approx.)

Control sera (Fig. 5, overleaf) exposed to heatinactivated antiserum, and antiserum previously incubated with the lysosomal fraction (F3) had no effect on the distribution of intracellular acid phosphatase in the fibroblasts. Thus, in these cultures, cell death following treatment with antiserum is accompanied by the almost immediate release of acid phosphatase from the affected cells. 


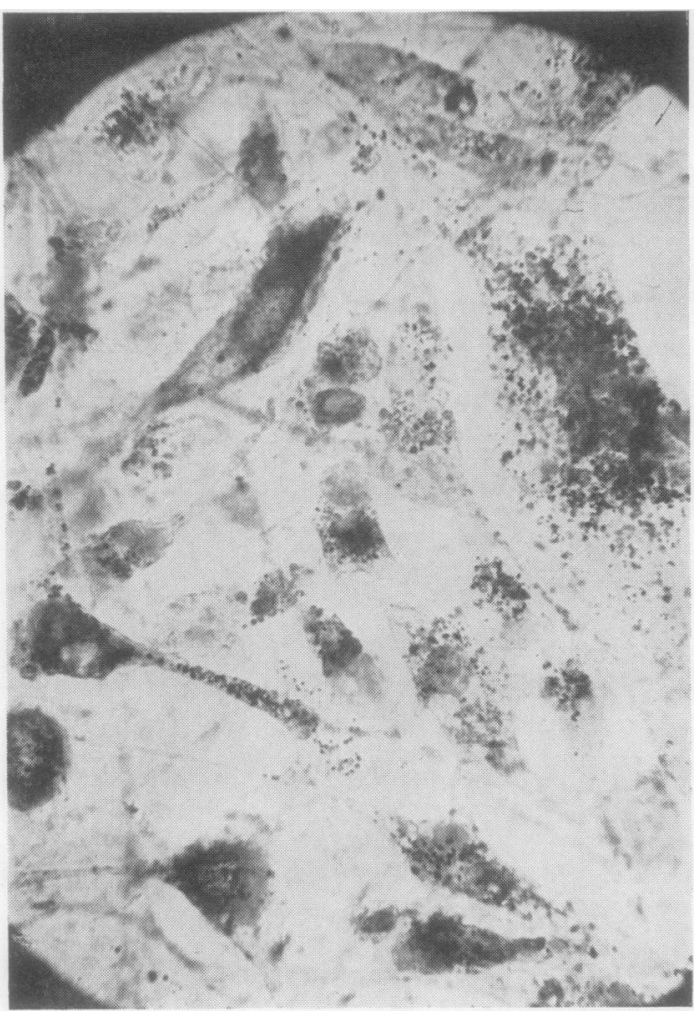

Fig. 5.-Rat fibroblasts stained for acid phosphatase after 1 hour's exposure to 20 per cent. heat-inactivated "antiserum". ( $\times 450$ approx.)

\section{Influence of Hydrocortisone on Actions of Antiserum}

One series of cultures was grown for over 24 hours in normal medium which contained $25 \mu \mathrm{g} . / \mathrm{ml}$. hydrocortisone sodium succinate ("Solu-cortef, Upjohn Co., Kalamazoo); when test medium 199, containing both 15 per cent. antiserum and $25 \mu \mathrm{g} . / \mathrm{ml}$. hydrocortisone sodium succinate, was added to these cultures, the cells were killed, but the acidphosphatase positive granules remained intact even 2 hours after exposure to the antiserum (Fig. 6). A similar protective effect on the lysosomes was noted when medium containing both antiserum and hydrocortisone was added to cells previously cultured in the absence of hydrocortisone, but after 24 hours' exposure to hydrocortisone and antiserum the cells no longer showed positive acid-phosphatase staining. Thus the hormone delays the action of the antiserum that results in lysosomal breakdown.

\section{Discussion}

Neuberger (1960) said that "to the histologist the most significant phenomenon, in a variety of rheu-

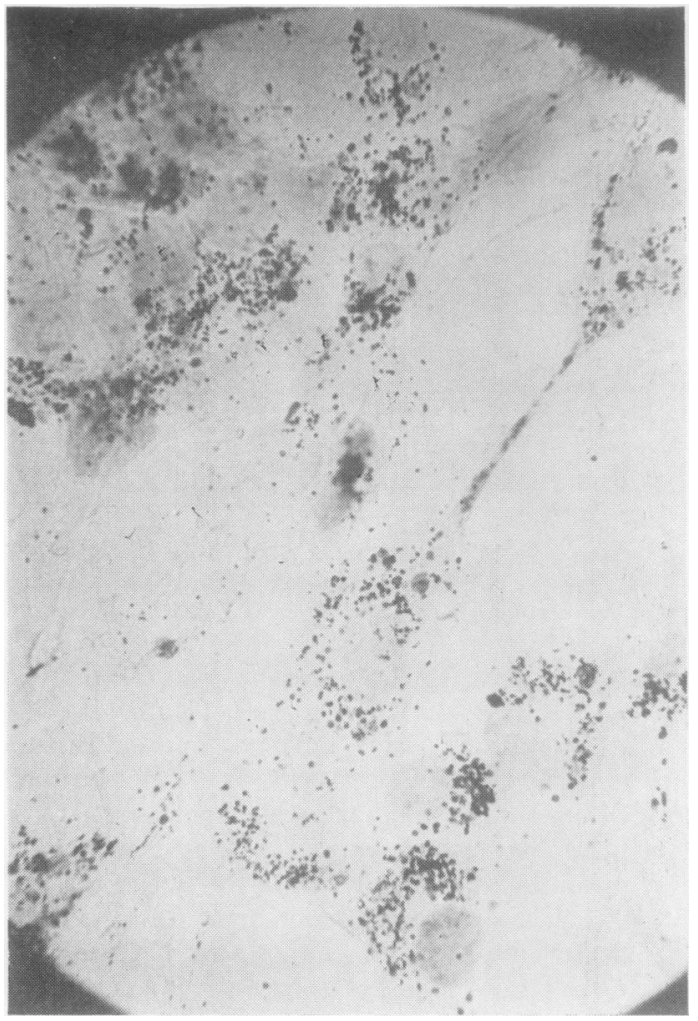

Fig. 6.-Rat fibroblasts stained for acid phosphatase after 1 hour's exposure to 20 per cent. "antiserum" $+25 \mu \mathrm{g} . / \mathrm{ml}$. hydrocortisone. ( $\times 450$ approx.)

matic and similar diseases, is the fibrinoid degeneration of collagenous tissue". He went on to say that "it may be assumed that the enzymes which break down collagen are supplied by the cells of the connective tissues, possibly the fibroblasts, and the rate of collagen metabolism may be regulated by hormones and other factors".

Recent studies at the Strangeways Laboratory (Dingle, Lucy, and Fell, 1961; Lucy, Dingle, and Fell, 1961) have shown that cartilage cells contain enzymes which, when active, are capable of degrading the extracellular components of the matrix; normally these enzymes are bound within cytoplasmic granules: the lysosomes (Dingle, 1961; Fell and Dingle, 1963).

It has been suggested (Dingle, 1962a, b) that the destruction of articular cartilage in arthritic diseases is related to the activation of lysosomal enzymes in cells that are closely opposed to the cartilage. Evidence in support of this view comes from the recent work of Luscombe (1963) who has found a significant increase in the level of the lysosomal 
enzymes, acid phosphatase, and cathepsin, in rheumatoid synovial tissue.

Although this hypothesis indicates a possible mechanism for the degradative changes that are known to occur in some connective tissue diseases, how these particles are activated in such cases is unknown. Lysosomal enzymes may be released by a variety of physical and chemical methods in vitro and by one or two compounds of physiological importance in vivo (de Duve, 1959; Dingle, Sharman, and Moore, 1963), but unfortunately this information does not throw much light on the mechanism of activation of lysosomes in disease processes.

In recent years the possible immunological basis of rheumatic diseases has received considerable attention (Glynn, 1962). If the immunological concepts are correct, the antigen-antibody reaction may be concerned in the activation of lysosomal enzymes in vivo. Some support for this view is provided by the results described in this paper.

Our experiments have shown that after the injection of a partially-purified lysosomal preparation into rabbits, antibodies are formed that react with the original antigen preparation; these results do not imply that we have produced antibodies to lysosomes alone since, as mentioned above, the original antigenic preparation does not consist entirely of these organelles. It is interesting that this antiserum does not release acid hydrolases from isolated lysosomal particles but, when it is added to intact fibroblasts at $37^{\circ} \mathrm{C}$., loss of acid phosphatase is demonstrable almost immediately. Although release of the lysosomal enzymes into the culture fluid has not yet been demonstrated, it is thought that disappearance of acid phosphatasestaining from the fibroblasts may be associated with an increased release of lysosomal enzymes into the medium like that observed in preparations of rat liver slices treated with the antiserum. The time differences between the response of the monolayers of fibroblasts and that of the liver slices, may be due to different rates of diffusion of the antiserum in the two systems, although other factors may also operate.

Although in the present experiments the release of lysosomal enzymes is accompanied by cell death, this association is not invariable, and a reversible activation has been demonstrated cytochemically in mouse ascites tumour cells treated with antibodies (Bitensky and Gahan, 1962). Further experiments are in progress to find whether enzymes can be released from cells by sub-lethal concentrations of antibodies.

The cytopathic changes in the cultures are similar to those described for other tissues treated with antibodies (Niven, 1929; Abramoff, Saunders, and Gasseling, 1961) or auto-antibodies (Pulvertaft, Doniach, Roitt, and Vaughan Hudson, 1959); we can offer no suggestions as to the mechanism of this reaction, though the fact that heated antiserum has no effect would suggest that complement is involved.

Fraser and Catt (1961) reported the toxic effect of serum from patients suffering from rheumatoid arthritis on cultures of synovial cells; they noted that some cells recovered from damage after 48 hours and that the cytotoxicity of serum was not inhibited by heat treatment. These differences between our results and those of Fraser and Catt do not necessarily indicate that we are observing different phenomena, since the irreversibility of the cytotoxic effects in our experiments may be due to the use of a higher concentration of antiserum than that employed by Fraser and Catt; although these authors stated that heating to $56^{\circ} \mathrm{C}$. did not abolish the cytotoxic effect of their sera, nevertheless they added guinea-pig complement to their system.

The fact that the cytotoxic and enzyme-releasing properties of the antiserum were not eliminated by incubation with rat erythrocytes suggests that the antiserum did not react with species-specific antigenic groups common to either fibroblasts or liver cells, since these are also present in rat erythrocytes. The inhibitory effect of hydrocortisone on lysosomalenzyme release by antibody resembles the protection of isolated rat liver lysosomes (Weissmann and Dingle, 1961) and of foetal rat skin in culture (Weissmann and Fell, 1962) against ultra-violet irradiation, and that of rat liver lysosomes against bacterial endotoxin (Thomas, McCluskey, and $\mathrm{Li}$, 1962).

In the present studies, when hydrocortisone was added to cultures at the same time as the antiserum, the lysosomes were protected as effectively as when the cells were cultured in the presence of the steroid before exposure to the antiserum. This would suggest that the steroid is very rapidly taken up by the cells. Furthermore, since lysosomes are stabilized even when the other cellular components are obviously damaged, it would seem that the site of action of this steroid is neither the cell surface nor the major cytoplasmic components, but lies perhaps within the lysosomal membrane.

Considerable caution must be exercised when considering the results of these experiments in relation to the possible role of lysosomal enzymes in disease processes, since our observations refer to cytotoxic concentrations of antiserum. It would seem, however, that under certain conditions, the 
activation of lysosomes in an immunological process might be possible, and that the enzymes, once released, would have a rapid and drastic effect upon the connective tissue components. Considerations of hydrogen ion concentration at the surface of both cells and macromolecules recently discussed by Weiss $(1963 \mathrm{a}, \mathrm{b})$ suggest that conditions for the action of these acid hydrolases in vivo may be much nearer the optimum than had previously been believed.

It is thought that the hypothesis outlined above indicates a possible mechanism for the degenerative changes in certain connective tissue diseases and may make possible a rational approach to the pharmacological control of tissue damage in the acute phase of these diseases.

\section{Summary}

Some effects are described of exposing rat liver lysosomes in suspension, rat liver slices, and cultures of rat "fibroblasts" to an antiserum prepared by injecting rabbits with partially purified rat liver lysosome preparations.

The loss of (lysosomally) bound acid phosphatase after exposure to antiserum was demonstrated in both the liver slices and cell cultures, but not in the lysosome suspension. From this it was concluded that the antiserum was not acting directly on the lysosomes to effect enzyme release. Under the described experimental conditions the release of acid phosphatase is inhibited by $25 \mu \mathrm{g}$. $/ \mathrm{ml}$. hydrocortisone, and by heat inactivation of the antiserum.

It is suggested that the experiments give general support to the hypothesis that the histological picture seen in a variety of rheumatic diseases could be produced by enzymes released from cells as part of a response to antibodies.

We are grateful to Dame Honor Fell, F.R.S., and Dr. R. R. A. Coombs for their helpful criticism of our manuscript, to Mr. J. Richards and Dr. J. M. Boissard for carrying out the Ouchterlony plate experiments and complement-fixation tests, and to Miss A. Glauert for the electron micrograph.

\section{REFERENCES}

Abramoff, P., Saunders, J. W., and Gasseling, M. T. (1961). J. nat. Cancer Inst., 26, 585.

Anson, M. L. (1938). J. gen. Physiol., 22, 79.

Bitensky, L., and Gahan, P. B. (1962). Biochem. J., 84, $13 P$.

Daniel, M. R., Dingle, J. T., and Lucy, J. A. (1961). Exp. Cell. Res., 24, 88.

Dingle, J. T. (1961). Biochem. J., 79, 509.

- (1962a). Proc. roy. Soc. Med., 55, 109.
Dingle, J. T. (1962b). "Conference on the Causes and Treatment of Rheumatic Diseases held at Ashridge College, 1962." Nuffield Foundation.

—, Lucy, J. A., and Fell, H. B. (1961). Biochem. J., 79, 497.

—, Sharman, I. M., and Moore, T. (1963). Proc. Nutrit. Soc., 22, X.

Duve, C. de (1959). In "Subcellular Particles: Symposium of Society of General Physiologists, 1958", ed. T. Hayashi, p. 128. Ronald Press, New York.

Fell, H. B., and Dingle, J. T. (1963). Biochem. J., 87, 403.

Fraser, J. R. E., and Catt, K. J. (1961). Lancet, 2, 1437.

Glynn, L. E. (1962). In "Scientific Basis of Medicine. Annual Reviews, 1962", p. 94. Athlone Press, London.

Gomori, G. (1952). "Microscopic Histo-chemistry". University of Chicago Press.

Lucy, J. A., Dingle, J. T., and Fell, H. B. (1961). Biochem. J., 79, 500.

Luscombe, M. (1963). Nature (Lond.), 197, 1010.

McIlwain, H., and Buddle, H. L. (1953). Biochem. J., $53,412$.

Morgan, J. F., Morton, H. J., and Parker, R. C. (1950). Proc. Soc. exp. Biol. (N.Y.), 73, 1.

Neuberger, A. (1960). "Heberden Oration, 1959", Ann. rheum. Dis., 19, 1.

Niven, J. S. F. (1929). J. Path. Bact., 32, 527.

Pulvertaft, R. J. V. (1959). In "Modern Trends in Pathology", ed. D. H. Collins, p. 19. Butter worth, London.

—, Doniach, D., Roitt, I. M., and Vaughan Hudson, R." (1959). Lancet, 2, 214.

Roy, A. B. (1958). Biochem. J., 68, 519.

Torriani, A. (1960). Biochim. biophys. Acta (Amst.), 38, 460.

Thomas, L., McCluskey, R. T., and Li, J. (1962). Fed. Proc., 21, 467.

Umbreit, W. W., Burris, R. H., and Stauffer, J. F. (1957). "Manometric Techniques", 3rd ed. Burgess, Minneapolis.

Weiss, L. (1963a). Biochem. Soc. Symp., 22, 32.

- (1963b). J. gen. Microbiol., 32, 331.

Weissmann, G., and Dingle, J. T. (1961). Exp. Cell. Res., 25, 207.

— and Fell, H. B. (1962). J. exp. Med., 116, 365.

Activation des lysosomes relativement à la maladie du tissu conjonctif

\section{RÉSUMÉ}

On décrit certains effets qu'on obtient lorsqu'on soumet des lysosomes du foie de rat en suspension, des coupes du foie de rat et des "fibroblastes" du rat à un antisérum provenant de lapins à qui on avait injecté des préparations partiellement purifiées de lysosomes du foie de rat.

Une perte de phosphatase acide liée (aux lysosomes) en présence de l'antisérum a été démontrée dans les coupes de foie et les cultures cellulaires, mais non pas dans la suspension des lysosomes. On en conclut que l'antisérum n'agissait pas directement sur les lysosomes 
pour libérer l'enzyme. Sous les conditions expérimentales décrites ci-dessus, la libération de la phosphatase acide est inhibée par $25 \mu \mathrm{g}$. $/ \mathrm{ml}$. d'hydrocortisone et par l'inactivation à la chaleur de l'antisérum.

On pense que ces expériences, en général, viennent à l'appui de l'hypothèse selon laquelle le tableau histologique observé dans un grand nombre des maladies rhumatismales serait produit par des enzymes libérés par des cellules et que ce phénomène ferait partie de la réaction aux anticorps.

Activación de lisosomas en relación con la enfermedad del tejido conectivo

\section{Sumario}

Se describen ciertos efectos obtenidos cuando se somete lisosomas del hígado de rata en suspensión, cortes de hígado de rata y "fibroblastos" del hígado de rata a un antisuero procedente de conejos, a los cuales se había inyectado preparaciones parcialmente purificadas de lisosomas del hígado de rata.

Una pérdida de fosfatasa ácida ligada (a lisosomas) en presencia del antisuero fué demostrada tanto en los cortes de hígado como en las culturas celulares, pero no en la suspensión de lisosomas. Se concluye que el antisuero no tiene efecto directo sobre los lisosomas para producir la liberación del enzima. En condiciones experimentales descritas, la liberación de la fosfatasa ácida se ve inhibida por $25 \mu \mathrm{g}$. $/ \mathrm{ml}$. de hidrocortisona y por inactivación del antisuero por el calor.

Se sugiere que estos experimentos, en general. fortalecen la hipótesis según la cual el cuadro histológico observado en varias enfermedades reumáticas fuera producido por enzimas liberados por las células como parte de la reacción a los anticuerpos. 